\title{
PENERAPAN MODEL PEMBELAJARAN PROBLEM SOLVING UNTUK MENINGKATKAN KEMAMPUAN BERPIKIR KRITIS SISWA MENYELESAIKAN MASALAH SEGI EMPAT DAN SEGITIGA
}

\author{
Nesti Surya Astuti Zebua \\ Universitas Katolik Santo Thomas, Medan; \\ nestisuryaastutizebua101197@gmail.com
}

\begin{abstract}
Abstrak. Penelitian ini bertujuan untuk mengetahui apakah penerapan model pembelajaran Problem Solving dapat meningkatkan kemampuan berpikir kritis matematis siswa. Jenis penelitian ini merupakan Penelitian Tindakan Kelas (PTK). Subjek dalam penelitian ini adalah siswa kelas VII SMP Santo Yoseph Medan, yang terdiri dari 32 siswa. Objek dalam penelitian ini adalah model pembelajaran Problem Solving untuk meningkatkan kemampuan berpikir kritis siswa dalam menyelesaikan masalah matematika. Berdasarkan analisis data penelitian, diperoleh hasil yaitu: pada tes kemampuan awal berpikir kritis matematis siswa masih tergolong rendah yaitu diperoleh rata-rata klasikal sebesar 49,84, siswa yang tuntas sebanyak 8 orang dengan persentase $25 \%$ sedangkan siswa yang tidak tuntas sebanyak 24 orang dengan persentase $75 \%$. Hasil tes siklus I setelah menggunakan model pembelajaran Problem Solving diperoleh nilai rata-rata klasikal sebesar 63,90 , siswa yang tuntas sebanyak 17 orang dengan persentase 53,12\% sedangkan siswa yang tidak tuntas sebanyak 15 orang dengan persentase $46,87 \%$. Pada siklus II setelah melakukan perbaikan pembelajaran model Problem Solving memperoleh peningkatan nilai ratarata klasikal sebesar 75,78 siswa yang tuntas sebanyak 26 orang dengan persentase $81,25 \%$ sedangkan siswa yang tidak tuntas sebanyak 6 orang dengan persentase $18,75 \%$. Jadi dapat disimpulkan bahwa model pembelajaran Problem Solving yang telah diterapkan dapat meningkatkan kemampuan berpikir kritis matematis siswa. Hal ini didukung dengan diperolehnya data rata-rata ketuntasan klasikal kemampuan berpikir kritis matematis siswa yang diperoleh dengan model pembelajaran Problem Solving pada siklus II lebih tinggi dari siklus I.
\end{abstract}

Kata Kunci. Model Problem Solving, berpikir kritis matematis.

Cartesius: Jurnal Pendidikan Matematika Vol. 2, No. 2

CProdi Pendidikan Matematika Universitas Katolik Santo Thomas 


\begin{abstract}
This study aims to determine whether the application of the Problem Solving learning model can improve students' mathematical critical thinking skills. This type of research is Classroom Action Research (CAR). The subjects in this study were students of class VII SMP Yos Yoseph Medan, which consisted of 32 students. The object in this study is the Problem Solving learning model to improve students' critical thinking skills in solving mathematical problems. Based on the analysis of research data, the results obtained are: the initial test of mathematical critical thinking ability of students is still relatively low that is obtained a classical average of 49.84, as many as 8 students who completed $25 \%$ with a percentage of $25 \%$ while students who did not complete as many as 24 people with $75 \%$ percentage. The results of the first cycle test after using the Problem Solving learning model obtained a classical average value of 63.90, 17 students completed with a percentage of $53.12 \%$, while students who did not complete as many as 15 people with a percentage of $46.87 \%$. In the second cycle after making improvements to the learning model Problem Solving obtained an increase in the classical average value of 75.78 students who completed 26 students with a percentage of $81.25 \%$ while students who did not complete as many as 6 people with a percentage of $18.75 \%$. So it can be concluded that the Problem Solving learning model that has been applied can improve students' mathematical critical thinking skills. This is supported by the data obtained by the average classical completeness of students' mathematical critical thinking skills obtained by the Problem Solving learning model in cycle II higher than cycle I.
\end{abstract}

Keywords. Model problem solving, mathematical critical thinking.

\title{
PENDAHULUAN
}

Dalam menempuh dunia yang penuh persaingan saat ini diperlukan sumber daya manusia yang mempunyai kemampuan berpikir tingkat tinggi dalam menyelesaikan berbagai masalah yang dihadapi. Kurniawan (2016: 48) menyatakan bahwa "Salah satu komponen berpikir tingkat tinggi yang banyak menjadi fokus pembelajaran Abad-21 adalah keterampilan berpikir kritis". Berpikir kritis merupakan salah satu tingkat tertinggi seseorang dalam berpikir, yaitu dimulai ingatan (recall), berpikir dasar (basic thinking), berpikir kritis (critical thinking), dan berpikir kreatif (creative thinking). Berpikir yang tingkatnya di atas ingatan (recall) dinamakan penalaran (reasoning). Sementara berpikir yang tingkatnya di atas berpikir dasar dinamakan berpikir tingkat tinggi (high order thinking).

Cartesius: Jurnal Pendidikan Matematika Vol. 2, No. 2

CProdi Pendidikan Matematika Universitas Katolik Santo Thomas 
Ditinjau dari kedalaman atau kekompleksan kegiatan matematika yang terlibat, berpikir matematika dapat klasifikasikan dalam berpikir matematik tingkat rendah (low order mathematical tinking) dan berpikir matematik tingkat tinggi (high order mathematical thinking), Sumarmo (dalam Abdullah, 2013: 67). Berpikir matematik tingkat rendah mencakup: pemahaman tingkat rendah, seperti mengenal dan menghafal rumus serta menggunakan dalam perhitungan rutin/algoritmik (pemahaman: mekanikal, komputasional, instrumental, knowing how to). Berpikir matematik tingkat tinggi meliputi: pemahaman tingkat tinggi (pemahaman: rasional, relasional, fungsional, knowing), berpikir kritis matematis, kreatif matematis dan intuitif. Selain berdasarkan kedalaman atau kekompleksan kegiatan matematika, berpikir matematis dapat dikelompokkan berdasarkan jenis kemampuannya dalam matematika yaitu: (1). Pemahaman konsep; (2). Pemecahan masalah; (3). Penalaran dan pembuktian; (4). Komunikasi; (5). Koneksi; (6) Representasi.

Menurut Abdullah (2013: 66), "Seseorang yang memiliki kemampuan tinggi harus dapat berpikir logis, rasional, kritis dan kreatif". Kemampuan berpikir tingkat tinggi tidak dapat terjadi dengan sendirinya, melainkan diperoleh melalui proses pendidikan khususnya pendidikan matematika di sekolah. Kemampuan berpikir logis, rasional, kritis dan kreatif termasuk dalam kemampuan berpikir tingkat tinggi.

Salah satu yang diajarkan kepada semua peserta didik mulai dari sekolah dasar hingga tingkat perguruan tinggi adalah matematika. Dalam pembelajaran matematika diharapkan tidak hanya mengajarkan fakta dan konsep, tetapi juga harus membekali peserta didik dalam memecahkan masalah yang dialami dalam kehidupan sehari-hari. Hal tersebut sejalan dengan pendapat Hendriana dan Soemarno (2014: 9) menyatakan bahwa, belajar matematika tidak hanya dengan menghafalal rumus-rumus dan prosedur-prosedur serta konsep-konsep pengerjaannya, tetapi dengan memahami makna dari apa yang sedang dipelajari.

Matematika memegang peranan penting untuk pengembangan kemampuan berpikir kritis siswa. Meningkatkan kemampuan berpikir kritis dipandang

Cartesius: Jurnal Pendidikan Matematika Vol. 2, No. 2

CProdi Pendidikan Matematika Universitas Katolik Santo Thomas 
sebagai sesuatu yang sangat penting untuk diupayakan guru di sekolah agar siswa mampu dan terbiasa menghadapi berbagai permasalahan di sekitarnya.

Kemampuan berpikir kritis adalah suatu kemampuan menelaah, menganalisis dan mengorganisasikan terhadap informasi yang didapat, diperiksa dan dibandingkan dahulu kebenarannya dengan pengetahuan dan pemahaman yang dimiliki sebelumnya sehingga seorang tersebut mampu memberikan kesimpulan terhadap informasi tersebut dengan alasan yang cepat dan tepat. Menurut Cabera (dalam Fachrurazi, 2011), "Kemampuan berpikir kritis tidak hanya sebagai tujuan pendidikan semata, tetapi juga sebagai proses fundamental yang memungkinkan siswa untuk mengatasi berbagai permasalahan masa mendatang di lingkungannya". Untuk itu dalam proses belajar mengajar, guru tidak boleh mengabaikan penguasaan kemampuan berpikir kritis. Siswa yang mampu berpikir kritis matematis akan cenderung memiliki sikap yang positif terhadap matematika, sehingga akan berusaha menalar dan mencari strategi penyelesaian masalah matematika.

Kemampuan berpikir kritis yang dimiliki siswa akan sangat berguna bagi masa depannya karena siswa yang memiliki kemampuan berpikir kritis dapat menyimpulkan dan menentukan tindakan yang dilakukan untuk menyelesaikan masalah yang akan hadapi. Menurut Ennis (dalam Kusmanto 2014 : 95-96), “Ada 12 indikator kemampuaan berpikir kritis yang diklasifikasikan menjadi 5 aspek kemampuan berpikir kritis, yaitu: (1) Memberikan penjelasan secara sederhana (meliputi: memfokuskan pertanyaan, menganalisis pertanyaan, bertanya dan menjawab pertanyaan tentang suatu penjelasan). (2) Membangun keterampilan dasar (meliputi: mempertimbangkan apakah sumber dapat dipercaya atau tidak, mengamati dan mempertimbangkan suatu laporan hasil observasi). (3) Menyimpulkan (meliputi: mendeduksi dan mempertimbangkan hasil deduksi, menginduksi dan mempertimbangkan hasil induksi, membuat dan menentukan nilai pertimbangan). (4) Memberikan penjelasan lanjut (meliputi: mendefinisikan istilah dan pertimbangan definisi dalam tiga dimensi, mengidentifikasi

Cartesius: Jurnal Pendidikan Matematika Vol. 2, No. 2

CProdi Pendidikan Matematika Universitas Katolik Santo Thomas 
asumsi). (5) Mengatur strategi dan taktik (meliputi: menentukan tindakan, berinteraksi dengan orang lain)". Dengan demikian diperlukan adanya suatu model pembelajaran yang mampu membangun pengetahuan dan kemampuan berpikir kritis dan disposisi pada diri siswa.

Fakta rendahnya hasil belajar siswa dapat berdasarkan observasi yang dilakukan di kelas VII SMP Swasta Katolik Santo Yoseph Medan Tahun Pelajaran 2018/2019 pada tanggal 30 Januari. Dalam proses pembelajaran di kelas, terlihat guru menjelaskan materi pembelajaran dan membahas contoh soal bersama siswa. Siswa mencatat materi dan contoh soal serta mengerjakan latihan yang diberikan oleh guru. Selama proses mengerjakan soal, terlihat siswa belum memahami konsep yang diberikan guru. Siswa juga kesulitan dalam mengaplikasikan konsep yang diberikan guru ketika diberi persoalan yang berbeda dari contoh soal. Keadaan ini terjadi disebabkan karena siswa hanya menghafal rumus-rumus yang diberikan tanpa memahaminya dan siswa tidak terlatih dalam menyelesaikan masalah matematika karena guru hanya memberikan soal-soal biasa.

Selain observasi, dilakukan juga wawancara dengan salah seorang guru matematika yaitu Bapak R. Simaremare. Dari hasil wawancara, diperoleh informasi bahwa proses pembelajaran yang berlangsung masih berpusat pada guru dan siswa kurang aktif dalam menanggapi materi sehingga hal ini menyebabkan proses pembelajaran belum sesuai dengan yang diharapkan. Peneliti juga memberikan minitest di kelas VII pada tanggal 02 Februari 2019, diperoleh data dari 32 orang siswa. Hasil minitest tersebut: Ada 9 siswa (8.12\%) mampu mengoservasi soal dengan baik, dan 15 siswa (46,8\%) tidak mampu mengobservasi soal dengan baik. Ada 10 siswa (31,5\%) yang mampu mendefinisikan istilah pada soal, dan 13 siswa (40,6\%) tidak mampu mendefinisikan istilah pada soal. Ada 7 siswa (21,87\%) memahami strategi dan taktik mengerjakan soal, dan 18 siswa (56,5\%) tidak memahami strategi dan taktik mengerjakan soal dengan baik.

Rendahnya kemampuan berpikir kritis siswa dari data yang diperoleh dapat terjadi karena siswa terbiasa hanya menghafal rumus dan kurang

Cartesius: Jurnal Pendidikan Matematika Vol. 2, No. 2

CProdi Pendidikan Matematika Universitas Katolik Santo Thomas 
mampu menggunakan konsep yang terkandung dalam rumus tersebut. Kurangnya kemampuan berpikir kirtis siswa sehingga pembelajaran kurang efektif. Siswa terbiasa lebih pasif dan bergantung pada guru sehingga tidak memiliki kesempatan untuk mengembangkan pengetahuan dan kemampuan berpikirnya. Dari kondisi-kondisi yang sudah dijabarkan di atas, dapat disimpulkan bahwa aktivitas siswa dalam proses pembelajaran kurang aktif.

Keberhasilan proses pembelajaran tergantung bagaimana guru menggunakan model pembelajaran yang tepat. Sipayung dan Simanjuntak (dalam Sianturi 2018:31) menyatakan bahwa guru mempunyai peran yang penting dalam mengusahakan memperbaiki mutu pendidikan. Dalam pembelajaran matematika yang sudah ada, guru belum sepenuhnya memberikan kesempatan kepada siswa untuk mengembangkan kemampuan berpikir kritisnya. Guru terbiasa meminta siswa untuk memberikan jawaban yang benar, mendefinisikan, mendeskripsikan, tanpa mendorong siswa dalam menimbulkan ide-ide baru, menganalisis, menghubungkan, mengevaluasi dan memikirkan ulang.

Salah satu model pembelajaran yang dapat digunakan sebagai upaya dalam meningkatkan kemampuan berpikir kritis siswa adalah model pembelajaran problem solving. Pepkin (dalam Shoimin 2014: 135) Problem solving adalah suatu model pembelajaran yang melakukan pemusatan pada pengajaran dan keterampilan pemecahan masalah yang diikuti dengan penguatan keterampilan. Dalam hal ini masalah didefinisikan sebagai suatu persoalan yang tidak rutin dan belum dikenal cara penyelesaiannya. Justru problem solving adalah mencari atau menemukan cara penyelesaiannya (menemukan pola, aturan). Langkah-langkah model pembelajaran problem solving menurut Aris Shoimin (2014: 137) yaitu, (1) siswa diberikan masalah dalam kehidupan sehari-hari sebagai pemecahan/diskusi, (2) siswa mengevaluasi, (3) siswa memberi kesimpulan, kemudian penerapan pemecahan masalah sekaligus pengujian kebenaran pemecahan masalah.

Model pembelajaran Problem Solving baik untuk diterapkan dalam meningkatkan kemampuan berpikir kritis dan hasil belajar siswa. Hal ini

Cartesius: Jurnal Pendidikan Matematika Vol. 2, No. 2

CProdi Pendidikan Matematika Universitas Katolik Santo Thomas 
berdasarkan hasil penelitian yang diteliti oleh Rahmawanty (2017: 207) dengan judul "Pengaruh Metode Pembelajaran Problem Solving Terhadap Kemampuan Berpikir Kritis Matematika". Hasil penelitian menunjukkan bahwa nilai rata-rata kemampuan berpikir kritis matematika kelas eksperimen yang menggunakan metode pembelajaran Problem Solving lebih tinggi daripada nilai rata-rata kemampuan berpikir kritis matematika kelas kontrol yang menggunakan metode pembelajaran Problem Based Learning. Hal ini ditunjukan dengan hasil uji $\mathrm{t}$ diperoleh nilai thitung $=5,093>t_{\text {tabel }}=$ 2,002 .

\section{METODE}

Pendekatan penelitian yang dilakukan pada penelitian ini yaitu dengan pendekatan campuran kuantitatif dan kualitatif. Pendekatan kuatitatif digunakan berkaitan dengan pengumpulan nilai dari hasil tes kemampuan awal dan tes kemampuan berpikir kritis matematis pada setiap siklus. Sementara pendekatan kualitatif digunakan berkaitan dengan data hasil lembar observasi kegiatan siswa dan guru. Metode penelitian yang digunakan pada penelitian ini adalah penelitian tindakan kelas Penelitian ini dilaksanakan di Kelas VII SMP Swasta Katolik Santo Yoseph Medan dengan jumlah siswa 32 orang pada semester genap tahun ajaran 2018/2019.

Tahapan disusun dalam 3 tahap penelitian, yaitu pra siklus, siklus 1,dan siklus 2. Pra siklus dilakukan untuk mengetahui pelaksanaan pembelajaran yang belum menggunakan model pembelajaran Problem Solving. Sedangkan siklus I dan siklus II terdiri atas perencanaan, pelaksanaan, pengamatan, dan refleksi. Pelaksanaan tiap tahap akan diambil satu kelas yang sama. Hal ini ditempuh untuk membandingkan dan menggambarkan proses pembelajaran pada tiap-tiap siklus.

Arikunto (2013: 211) menetapkan langkah-langkah dalam penelitian tindakan kelas yang disajikan pada gambar 1 berikut:

Cartesius: Jurnal Pendidikan Matematika Vol. 2, No. 2

CProdi Pendidikan Matematika Universitas Katolik Santo Thomas 


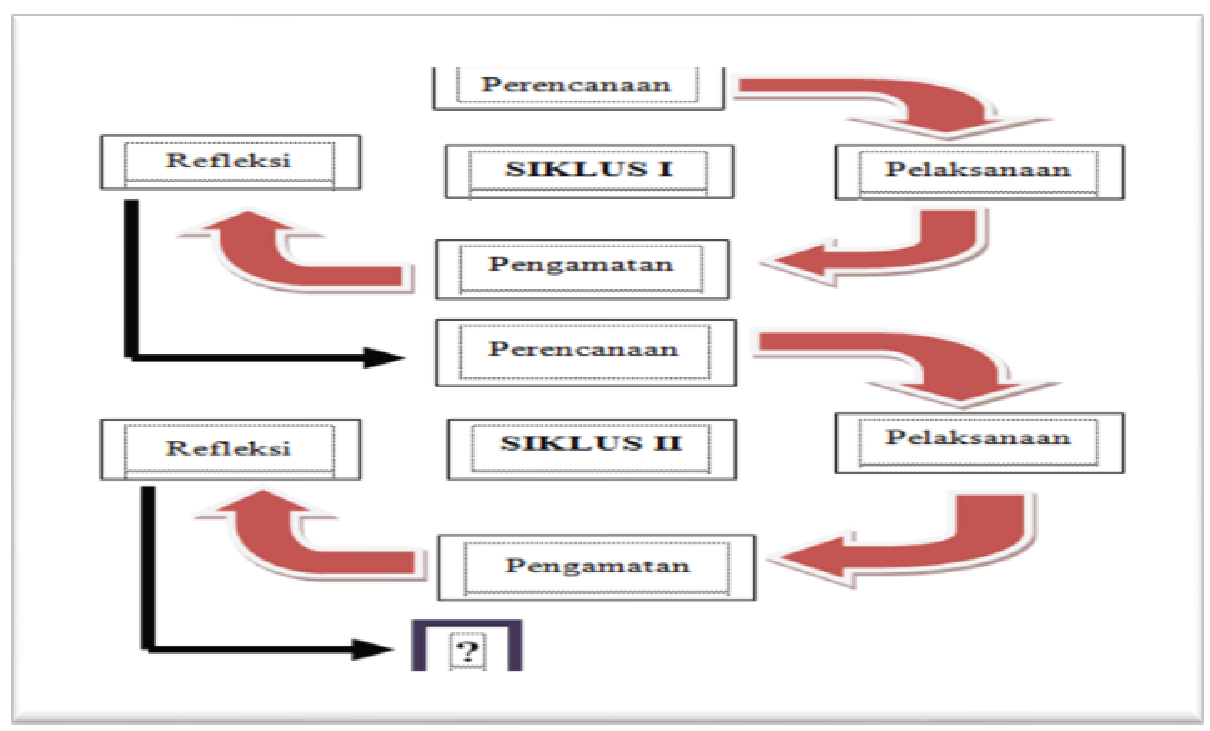

Gambar 1. Desain Penelitian Tindakan Kelas

\section{HASIL DAN PEMBAHASAN}

\section{Tahap Pelaksanaan Tindakan Siklus I}

Pertemuan ke-1 (RPP 1) dilaksanakan pada hari kamis 09 Mei 2019. Adapun materi yang dipelajari terkait segiempat dibatasi pada persegi, persegi panjang, dan jajargenjang. Pertemuan ke-2 (RPP 2) dilaksanakan pada hari Jumat 10 Mei 2019. Materi yang dipelajari masih mengenai segiempat yang dibatasi pada belah ketupat, trapesium, layang-layang. Dari hasil tes kemampuan berpikir kritis matematis siswa disimpulkan bahwa tingkat kemampuan berpikir kritis matematis siswa yang diperoleh 53,12\%, artinya bahwa tingkat kemampuan berpikir kritis matematis siswa meningkat dari sebelum dilakukan tindakan yaitu dengan melihat selisih peningkatan dari hasil tes kemampuan awal sampai tes kemampuan berpikir kritis siklus I sebesar 28\%, tetapi belum mencapai Persentase Ketuntasan Klasikal (PKK) yang ditetapkan peneliti yaitu $\geq 75 \%$, oleh sebab itu penelitian ini harus dilanjutkan ke siklus II.

\section{Pengamatan}

Hasil rata-rata persentase lembar observasi guru pertemuan ke-1 dan ke-2 adalah 71,66\% dengan kriteria "Baik". Namun hasil ini masih belum sesuai dengan yang diharapkan pada indikator keberhasilan. Hal ini terjadi karena

Cartesius: Jurnal Pendidikan Matematika Vol. 2, No. 2

CProdi Pendidikan Matematika Universitas Katolik Santo Thomas 
pada siklus I guru masih kurang dalam memaksimalkan waktu terkhusus dalam hal persentase kelompok di depan kelas.

Hasil rata-rata persentase lembar observasi siswa yaitu 62,45\% dengan kriteria "Baik". Namun masih ada beberapa hal yang perlu diperbaiki dalam proses pembelajaran, seperti dalam memahami masalah, masih ada beberapa siswa yang mengalami kesulitan memahami masalah yang diberikan guru. Dalam hal diskusi kelompok siswa masih ada yang kurang berkonsentrasi dan serius, hal ini disebabkan kurangnya kerja sama antar tiap kelompok. Pada siklus I motivasi siswa masih kurang baik dalam hal diskusi maupun dalam hal bertanya kepada guru.

\section{Refleksi}

Adapun beberapa masalah dan kelemahan yang terjadi pada pelaksanaan pembelajaran pada siklus I:

1. Guru masih kurang dalam mengatur waktu sehingga pembelajaran kurang optimal.

2. Siswa masih kurang bekerja sama dalam kelompok sehingga ada beberapa siswa yang kurang aktif dalam kelompoknya.

3. Siswa masih kurang percaya diri mempersentasikan hasil kelompoknya dan masih malu-malu di depan teman-temannya.

4. Dalam penerapan soal kemampuan berpikir kritis matematis, sebagian siswa belum terbiasa memahami maksud dari gambar yang ada disoal dan siswa masih harus dibimbing dalam menyelesaikan Lembar Aktivitas Siswa (LAS).

Berdasarkan indikator kinerja diperoleh bahwa:

1. Hasil Observasi aktivitas guru pada siklus I diperoleh persentase ratarata $71,66 \%$ dalam kategori "Baik".

2. Hasil observasi aktivitas siswa pada siklus I diperoleh presentase ratarata $62,45 \%$ dalam kategori "Baik".

3. Tes kemampuan berpikir kritis matematis siswa pada siklus I diperoleh ketuntasan klasikal yaitu PKK $=\frac{17}{32} \times 100 \%$ adalah $53,12 \%$ dengan ratarata $63,90 \%$ (ketuntasan klasikal belum tercapai yaitu $\geq 75 \%$ ).

Cartesius: Jurnal Pendidikan Matematika Vol. 2, No. 2

CProdi Pendidikan Matematika Universitas Katolik Santo Thomas 
Dapat disimpulkan bahwa siklus I belum mencapai indikator kinerja keberhasilan, maka dilanjutkan tindakan siklus II.

\section{Tahap Pelaksanaan Tindakan Siklus II}

Pertemuan ke-3 (RPP III)

Pembelajaran pada pertemuan ke-3 dilaksanakan pada hari kamis Rabu 15 Mei 2019. Adapun materi yang dipelajari terkait segitiga dibatasi pada mengenal jenis-jenis segitiga, sifat-sifatnya dan luas segitiga.Pertemuan ke-4 (RPP IV), Pembelajaran pertemuan ke-2 dilaksanakan pada hari kamis 16 Mei 2019. Materi yang dipelajari masih mengenai segitiga yang dibatasi pada luas dan keliling segitiga.

Setelah pelaksanaan tindakan II (RPP III dan IV) selesai, siswa diberikan tes yaitu tes kemampuan berpikir kritis matematis siswa untuk melihat peningkatan kemampuan berpikir kritis matematis siswa. Berdasarkan hasil tes kemampuan berpikir kritis matematis siswa secara klasikal diperoleh hasil kemampuan berpikir kritis siswa yaitu tinggi.

Berdasarkan hasil tes kemampuan berpikir kritis siklus II dapat disimpulkan bahwa tingkat kemampuan berpikir kritis siswa meningkat $81,25 \%$, artinya bahwa tingkat kemampuan berpikir kritis siswa meningkat dari siklus I dan sudah mencapai Tingkat Ketuntasan Klasikal (PKK) yang ditetapkan peneliti di atas 75\%. Hal ini menunjukkan bahwa penggunaan model Pembelajaran Problem Solving dapat meningkatkan kemampuan berpikir kritis siswa pada materi Segiempat dan segitiga di kelas VIII SMP Santo Yoseph Medan Tahun Pelajaran 2018/2019. Sehingga penelitian ini dapat dihentikan hanya sampai siklus II.

\section{Pengamatan}

Hasil dari rata-rata persentase lembar observasi guru yaitu 86,05\% dengan kriteria "Baik Sekali". Artinya bahwa rata-rata persentase aktivitas guru pada siklus I meningkat dari $71,66 \%$ menjadi $86,05 \%$ pada siklus II, maka indikator keberhasilan yang diterapkan tercapai yaitu besar dari 75\%. Hasil

Cartesius: Jurnal Pendidikan Matematika Vol. 2, No. 2

CProdi Pendidikan Matematika Universitas Katolik Santo Thomas 
dari persentase lembar observasi siswa pada pertemuan ke-2 adalah $90 \%$ dengan kriteria "Baik Sekali".

Hasil dari rata-rata persentase lembar observasi siswa pada siklus II yaitu 85\% dengan kriteria "Baik Sekali". Pada proses pembelajaran siswa sudah semakin lebih aktif dan sudah bisa memahami masalah yang diberikan oleh guru serta mampu berlomba untuk mempresentasekan hasil kelompoknya serta siswa juga sudah aktif dalam bertanya kepada setiap kelompok yang maju. Ketika berdiskusi, siswa sudah memiliki kerja sama yang baik, dimana ketua kelompok sudah terlihat memandu setiap anggotanya untuk berdiskusi.

\section{Refleksi}

Hasil analisis tes kemampuan berpikir kritis siswa pada siklus II diperoleh bahwa siswa yang belum memiliki kemampuan berpikir kritis sebanyak 6 orang $(18,75 \%)$, sedangkan siswa yang telah memiliki kemampuan berpikir kritis sebanyak 17 orang $(81,25 \%)$. berdasarkan hasil yang diperoleh ini maka secara klasikal dapat dikatakan siswa telah memiliki kemampuan berpikir kritis.

Hasil observasi guru pada siklus II yaitu sebesar 85\% atau kategori "Sangat Baik". begitu juga dengan observasi aktivitas siswa diperoleh hasil 85\% atau kategori "Sangat Baik". hal ini menunjukkan tindakan pembelajaran yang dilakukan dengan menggunakan dengan model Pembelajaran Problem Solving mengalami peningkatan yang sangat baik ketika dilaksanakan pada siklus II serta dapat meningkatkan kemampuan berpikir kritis siswa.

Tabel 1. Perbandingan Hasil Observasi Guru Pada Siklus I dan Siklus II

\begin{tabular}{ccccc}
\hline No. & Tindakan & Pertemuan & Persentase & Kriteria \\
\hline 1. & Siklus I & Ke-1 & $70 \%$ & Baik \\
& & Ke-2 & $73,3 \%$ & Baik \\
& & Rata-rata & $71,66 \%$ & Baik \\
2. & Siklus II & Ke-1 & $83,3 \%$ & Sangat Baik \\
& & Ke-2 & $88,8 \%$ & Sangat Baik \\
& & Rata-rata & $86,05 \%$ & Sangat Baik \\
\hline
\end{tabular}

Cartesius: Jurnal Pendidikan Matematika Vol. 2, No. 2

CProdi Pendidikan Matematika Universitas Katolik Santo Thomas 
Tabel 1 di atas menunjukkan bahwa persentase rata-rata pembelajaran matematika dengan menggunakan model Pembelajaran Problem Solving meningkat dari siklus I ke siklus II. Hal ini menunjukkan bahwa pelaksanaan pembelajaran dengan model Pembelajaran Problem Solving sudah terlaksana dengan baik sesuai dengan yang di harapkan.

Tabel 2. Perbandingan Hasil Observasi Siswa

Pada Siklus I dan Siklus II

\begin{tabular}{ccccc}
\hline No. & Tindakan & Pertemuan & Pertemuan & Kriteria \\
\hline 1. & Siklus I & Ke-1 & $53,7 \%$ & Cukup \\
& & Ke-2 & $71,2 \%$ & Baik \\
& Rata-rata & $62,45 \%$ & Baik \\
2. & Ke-1 & $80 \%$ & Baik \\
& & Ke-2 & $90 \%$ & Sangat Baik \\
& & Rata-rata & $85,3 \%$ & Sangat Baik \\
\hline
\end{tabular}

\section{Hasil Tes Siklus I dan Siklus II}

Tes diberikan pada tiap siklus yaitu siklus I dan siklus II yang terdiri dari 4 butir soal pada setiap siklus. Hasil tes siklus ini digunakan untuk mengetahui ada tidaknya peningkatan kemampuan berpikir kritis siswa dengan menggunakan model Pembelajaran Problem Solving dari siklus I dan II. Berdasarkan analisi hasil tes siklus I dan siklus II, secara klasikal diperoleh persentase dari 53,12\% menjadi $81,25 \%$. Ini artinya ada peningkatan kemampuan berpikir kritis siswa berdasarkan skor penilaian.

Gambaran umum perbandingan hasil kemampuan berpikir kritis siswa pada siklus I dan siklus II adalah sebagai berikut :

Tabel 3. Perbandingan Hasil Tes Siklus I dan Siklus II

\begin{tabular}{lcc}
\multicolumn{1}{c}{ Kategori } & Siklus I & Siklus II \\
\hline Nilai Tertinggi & 85 & 95 \\
Nilai Terendah & 25 & 55 \\
Jumlah Siswa Yang Tidak & 17 & 26 \\
Tuntas & & \\
Jumlah Siswa Yang Tuntas & 15 & 6 \\
\hline
\end{tabular}

Cartesius: Jurnal Pendidikan Matematika Vol. 2, No. 2

CProdi Pendidikan Matematika Universitas Katolik Santo Thomas 


\begin{tabular}{lcc}
\hline Rata-rata Nilai Siswa & 63,90 & 75,78 \\
Ketuntasan Klasikal & $53,12 \%$ & $81,25 \%$ \\
\hline
\end{tabular}

\section{KESIMPULAN}

Berdasarkan hasil analisis data dan hasil penelitian maka dapat diambil kesimpulan bahwa dengan menggunakan model pembelajaran Problem Solving dapat meningkatkan kemampuan berpikir kritis matematis siswa dalam pembelajaran. Hal ini dapat dilihat dari:

1. Tingkat kemampuan berpikir kritis matematis siswa di kelas VII SMP Santo Yoseph Medan sebelum dan sesudah penerapan model pembelajaran Problem Solving disimpulkan meningkat. Hal ini diperoleh dari data bahwa hasil tes kemampuan awal hanya sebanyak $25 \%$ siswa yang tuntas, pada tes kemampuan berpikir kritis matematis siswa siklus I sebanyak 53,12\% dan pada siklus II sebanyak 81,25\%.

2. Penerapan model pembelajaran Problem Solving dapat dilihat setelah pembelajaran pada siklus I dan siklus II dilakukan.

a. Sebelum pembelajaran dilakukan, diperoleh hasil analisis data yang menunjukkan bahwa tingkat kemampuan berpikir kritis matematis siswa dengan persentase ketuntasan belajar siswa yaitu sebesar 25\% pada tes kemampuan awal.

b. Setelah penerapan model pembelajaran Problem Solving diperoleh hasil analisis data yaitu $53,12 \%$ pada siklus I dan $81,25 \%$ pada siklus II.

c. Pelaksanaan pembelajaran melalui model pembelajaran Problem Solving pada materi segiempat dan segitiga sudah terlihat sangat baik yaitu dengan rata-rata di atas 75\%. Hal ini dapat dilihat dari lembar observasi aktivitas guru dan aktivitas siswa.

d. Dari hasil data yang diperoleh, dapat disimpulkan bahwa penerapan model pembelajaran Problem Solving dapat meningkatkan kemampuan berpikir kritis matematis siswa pada materi segiempat dan segitiga di kelas VII SMP Santo Yoseph Medan.

Adapun saran yang dikemukakan dari pelaksanaan penelitian tindakan kelas dan hasil penelitian yang telah diperoleh oleh peneliti adalah sebagai berikut:

Cartesius: Jurnal Pendidikan Matematika Vol. 2, No. 2

CProdi Pendidikan Matematika Universitas Katolik Santo Thomas 
1. Model pembelajaran Problem Solving dapat menjadi salah satu alternatif dalam pelaksanaan pembelajaran matematika karena dengan menggunakan model pembelajaran Problem Solving siswa dapat lebih aktif, semangat, menumbuhkan kerja sama antar siswa serta menumbuhkan rasa percaya diri siswa dalam bertindak sebagai guru di depan kelas.

2. Bagi guru agar menjadikan model pembelajaran Problem Solving menjadi salah satu pedoman dalam pelaksanaan pembelajaran matematika di kelas untuk meningkatkan kemampuan berpikir kritis matematis siswa.

3. Agar kemampuan berpikir kritis matematis siswa dapat semakin ditingkatkan dengan menggunakan model pembelajaran Problem Solving maka diharapkan selama proses pembelajaran berlangsung siswa terlibat secara langsung dalam proses pembelajaran.

4. Bagi peneliti selanjutnya, diharapkan dapat menindaklanjuti hasil penelitian dengan mengkaji lebih dalam lagi tentang penerapan model pembelajaran Problem Solving dan penerapannya dalam proses pembelajaran matematika khususnya pada materi segiempat dan segitiga.

\section{UCAPAN TERIMAKASIH}

Penulis menyampaikan terimakasih kepada Ibu Tetty Natalia Sipayung, S.Si., M.Pd. sebagai Dosen Pembimbing 1 dan Ibu Frida M. A. Simorangkir, S.Si., M.Pd. sebagai Dosen Pembimbing 2 yang telah mengarahkan dan membimbing penulis mulai dari awal penelitian hingga berakhirnya penelitian sehingga penulis dapat menuliskan artikel ini yang merupakan bagian dari hasil penelitian penulis. Penulis juga menyampaikan terimakasih kepada Kepala Program Studi Pendidikan Matematika, Dekan, dan Rektor Universitas Katolik Santo Thomas atas dukungan yang diberikan kepada penulis.

\section{DAFTAR PUSTAKA}

[1] Abdullah.2013. Berpikir Kritis Matematik. Jurnal Matematika Dan Pendidikan Matematika. Vol , No. 1. Html, diakses pada 3 April 2019 jam 21.30 WIB.

Cartesius: Jurnal Pendidikan Matematika Vol. 2, No. 2

CProdi Pendidikan Matematika Universitas Katolik Santo Thomas 
[2] Arikunto. 2010. Prosedur Penelitian Suatu Pendekatan Praktik. Jakarta: Rineka Cipta.

[3] Arikunto. 2013. Dasar - Dasar Evaluasi Pendidikan.Jakarta: Bumi Aksara.

[4] Ariyanto, dkk.2018. Penerapan Model Pembelajaran Problem Solving Untuk Meningkatkan Kemampuan Berpikir Kritis Dan Hasil Belajar Siswa. Jurnal Guru Kita (JGK). Vol 2 (3) Juni 2018. Html, diakses pada 4 April 2019 jam 19:50 WIB.

[5] Bey, dkk.2013. Penerapan Pembelajaran Problem Solving untuk Meningkatkan Aktivitas dan Hasil Belajar Matematika pada Materi SPLDV. Jurnal Pendidikan Matematika. Vol. 4, No. 2. Html, diakses pada 9 Februari 2019 jam 14.00 WIB.

[6] Fadillah.2016. Pengaruh Pembelajaran Problem Solving Terhadap Kemampuan Berpikir Kreatif Matematis Siswa. Jurnal Fibonacci Pendidikan Matematika \& Matematika Vol 2 No 1. Html, diakses pada 5 Februari 2019 jam 10.50 WIB.

[7] Hamdani. 2017. Strategi Belajar Mengajar.Bandung : CV Pustaka Setia.

[8] Husnidar, dkk.2014. Penerapan model pembelajaran berbasis masalah Untuk Meningkatkan Kemampuan Berpikir Kritis Dan Disposisi Matematis Siswa. Jurnal Didaktik Matematika ISSN: 2355-4185. Html, diakses pada 30 januari 2019 jam 11:30 WIB.

[9] Hasratuddin.2013. Membangun karakter melalui pembelajaran Matematika. Jurnal Pendidikan Matematika Paradikma, Vol 6 Nomor 2. Html, diakses pada 29 januari 2019 jam 15:45 WIB.

[10] Kurniawan.2016. Efektifitas pembelajaran Problem Solving Terhadap Keterampilan Berpikir Kritis Matematis. Jurnal FKIP.UNS. ISBN: 978602-6122-20-9. Html, diakses pada 5 Februari 2019 jam 12.50 WIB.

[11] Kusmanto.2014. Pengaruh Berpikir Kristis Terhadap Kemampuan Siswa Dalam Memecahkan Masalah Matematika (Studi Kasus Di Kelas VII SMP Wahid Hasyim Moga). Jurnal EduMa Vol.3 No.1 ISSN 2086 - 3918. Html, diakses pada 12 Februari 2019 jam 15.20 WIB.

[12] Muliawan, Jasa Ungguh. 2016. 45 Model Pembelajaran Spektakuler. Yokyakarta. AR-RUZZ MEDIA.

[13] Rahmawanty.2017. Pengaruh Metode Pembelajaran Problem Solving Terhadap Kemampuan Berpikir Kritis Matematika. Jurnal Kajian 
Pendidikan Matematika. ISSN 2477-2348. Html, diakses pada 10 Februari 2019 jam 11.10 WIB.

[14] Rusman.2017. Belajar \& Pembelajaran.Bandung : Kencana.

[15] Sanjaya, Wina. 2013. Penelitian Tindakan Kelas.Jakarta: Kencana.

[16] Setiawan, R. 2017. Penelitian Tindakan Kelas (Action Research). Yogyakarta: Nuha Medika.

[17] Shoimin, Aris. 2016. 68 Model Pembelajaran Inovatif dalam Kurikulum 2013. Jakarta : AR- Ruzz Media.

[18] Sianturi, dkk.2018. Pengaruh Model Problem Based Learning (PBL) Terhadap Kemampuan Berpikir Kritis Matematis Siswa SMPN 5 Sumbul. Union: Jurnal Pendidikan Matematika Vol 6 No 1. Html, diakses pada 30 januari 2019 jam 13:45 WIB.

[19] Soemarmo, Utari. 2014. Penilaian Pembelajaran Matematika.Bandung: PT Refika Aditama.

[20] Soemarmo, Utari. 2014. Penilaian Pembelajaran Matematika.Bandung: PT Refika Aditama.

[21] Sudjana, Nana. 2016. Penilaian Hasil Proses Belajar Mengajar.Bandung: PT Remaja Rosdakarya Offset.

[22] Susanto, Ahmad. 2017. Teori Belajar dan Pembelajaran di Sekolah Dasar. Jakarta : Kencana.

[23] Susanto, Ahmad. 2014. Teori Belajar dan Pembelajaran di Sekolah Dasar. Jakarta: Kencana Prenada Media Group

[24] Tampubolon, Saur. 2014. Penelitian Tindakan Kelas Sebagai Pengembangan Profesi Pendidik dan Keilmuan.Jakarta: Erlangga

[25] Wibowo, Janu.2016. "Peningkatan Hasil Belajar Dan Kemampuan Berpikir Kritis Matematika Siswa Di Kelas III Pada Materi Operasi Hitung Campuran Melalui Model Pembelajaran Kontekstual SD Negeri Plaosan 1 PGSD FKIP Universitas Sanata Dharma Yogyakarta"

Cartesius: Jurnal Pendidikan Matematika Vol. 2, No. 2

CProdi Pendidikan Matematika Universitas Katolik Santo Thomas 